\title{
Mould Infections of Traumatic Wounds: A Brief Narrative Review
}

Daniele Roberto Giacobbe (D) - Niccolò Riccardi • Antonio Vena •

Matteo Bassetti

Received: November 29, 2019 / Published online: February 18, 2020

(c) The Author(s) 2020

\section{ABSTRACT}

Mould infections may follow traumatic injuries, with direct fungal inoculum in the site of injury and subsequent angioinvasion, possibly resulting in tissue necrosis and systemic dissemination. The pathogenesis of mould infections following trauma injuries presents unique features compared with classical mould infections occurring in neutropenic or diabetic patients, because a large fraction of post-traumatic mould

Enhanced digital features To view enhanced digital features for this article go to https://doi.org/10.6084/ m9.figshare.11689266.

D. R. Giacobbe $(\varangle) \cdot$ A. Vena · M. Bassetti

Department of Health Sciences (DISSAL), University of Genoa, Genoa, Italy

e-mail: daniele.roberto.giacobbe@edu.unige.it

D. R. Giacobbe - A. Vena - M. Bassetti

Clinica Malattie Infettive, Ospedale Policlinico San

Martino, IRCCS, Genoa, Italy

N. Riccardi

Department of Infectious, Tropical Diseases and

Microbiology, IRCCS Sacro Cuore Don Calabria

Hospital, Negrar di Valpolicella, Verona, Italy infections is observed in previously healthy individuals. Most of the published clinical experience and research on mould infections following traumatic injuries regards soldiers and infections after natural disasters. However, following trauma and soil contamination (e.g., agricultural or automotive injuries) other immunocompetent individuals may develop mould infections. In these cases, delays in correct diagnosis and treatment may occur if pertinent signs such as necrosis and absent or reduced response to antibacterial therapy are not promptly recognized. Awareness of mould infections in at-risk populations is needed to rapidly start adequate laboratory workflow and early antifungal therapy in rapidly evolving cases to improve treatment success and reduce mortality.

Keywords: Aspergillus; Fusarium; Injury; Mucorales; Scedosporium; Trauma; Wound 


\section{Key Summary Points}

The pathogenesis of mould infections following trauma injuries presents unique features.

Delays in correct diagnosis and treatment may occur if pertinent signs such as necrosis and absent or reduced response to antibacterial therapy are not promptly recognized.

Most of the published clinical experience and research on mould infections following traumatic injuries involve military and natural disasters.

More research is needed to further optimize diagnostic and therapeutic algorithms outside classical categories at risk.

\section{INTRODUCTION}

Invasive fungal diseases caused by moulds are associated with high mortality [1]. They may develop, with different spectra of prevalence, involved organisms, and clinical presentations, in patients with congenital/acquired immune defects and in patients with uncontrolled diabetes mellitus or other chronic/acute comorbid conditions (e.g., mucormycosis in patients with uncontrolled diabetes mellitus or invasive pulmonary aspergillosis in patients with chronic obstructive pulmonary disease or in patients with severe influenza) [2, 3].

Mould infections may also follow traumatic injuries, with direct fungal inoculum in the site of injury and subsequent angioinvasion, possibly resulting in vessel thrombosis and tissue necrosis $[4,5]$. In this regard, penetrating traumas are a well-known risk factor for mucormycosis, especially amongst soldiers during campaigns war, although mould infections may also be observed in civilians experiencing severe trauma [6-8].
Owing to the ubiquitous nature of moulds, there are a variety of settings where traumatic injuries can result in mould infections, such as agricultural traumas, motor vehicles crashes, blast traumas, and natural disasters $[9,10]$. In such settings, contamination of open wounds with organic/environmental material and moulds can be followed by severe, necrotizing mould infections that, according to some published series, may need for surgical debridement or amputations in more than half of patients [11-13]. In similar situations, a high clinical suspicion and a timely diagnosis are pivotal to decrease mortality and avoid sequelae [13]. In addition, in some cases moulds can also disseminate through the bloodstream, leading to fungal meningitis, ophthalmitis, sinusitis, or osteomyelitis [1, 9, 14].

The aim of this review is to give a brief overview of the epidemiology, diagnosis, and treatment of wound mould infections following traumatic injuries. This article is based on previously conducted studies and does not contain any studies with human or animal subjects performed by either of the authors.

\section{METHODS}

In June 2019 we performed a MEDLINE/ PubMed search, employing various combinations of the following key words: mold*; mould*; traum*, human. The search period was from January 1990 to June 2019. Of the 1024 papers identified, 806 were excluded by title and abstract screening. The full texts of the remaining 218 papers and of pertinent references were then retrieved and discussed. The final decision on their inclusion in the present narrative review was based upon the subjective impression of the authors. The final draft was structured in the following paragraphs: (1) epidemiology and risk factors; (2) pathogenesis; (3) diagnosis; (4) treatment.

\section{Epidemiology and Risk Factors}

The reported incidence of post-traumatic mould infections among the general population is frequently unseparated from that of other types of 
mould infections, e.g., approximately $0.43-1.7$ cases per million persons have been reported for mucormycosis [4, 15-17]. Nonetheless, two important factors should be necessarily considered when interpreting these epidemiological data: (1) owing to the difficulties of diagnosing mould infections outside specific contexts, there could be an underestimation of incidence in the general population [18]; (2) incidence and prevalence of post-traumatic mould infections are undoubtedly higher in specific populations at risk (e.g., soldiers) $[4,10]$. It is also worth mentioning that an important factor hampering the comparison of incidence and/or prevalence data across different studies, even when conducted in similar populations, is the frequent use of different denominators (e.g., person-time, number of patients, number of patient at risk, number of patients with wound infection) [18]. Nonetheless, while keeping in mind these important limitations, two general features of the epidemiology of post-traumatic mould infections can be extrapolated from the available data.

The first is that, from the clinician's perspective, mould infections should always be suspected in patients presenting with infected wound and belonging to specific at-risk populations or in particular environmental conditions. For example, fungal infections were observed in $15 \%(9 / 60)$ of corn-picker hand injuries in a single-center study [19]. In another retrospective study of 1133 soldiers with injuries, fungal elements on histopathology and/or fungal growth from wounds was detected in $8.5 \%$ of cases (96/1133) [20]. Prevalence of mould infections following combat-related injuries peaked at $3.5 \%$ in another observational study among US military personnel [10]. Up to $11.7 \%$ prevalence of post-traumatic mould infections was observed in injured soldiers admitted to intensive care units [21]. Of note, combat-related injuries, by their nature, involve young people without any other comorbidity and/or immunosuppression and are thus one of the best example of how traumatisms are a key predisposing factor for mould infections (by altering not only mechanical defences, but possibly also by prompting a local/systemic immunosuppressed status)
$[4,22,23]$. Other factors, besides the occurrence of trauma itself, are also likely to increase the risk of wound mould infections in soldiers with injuries. In geographical areas of military operations, temperate climate, dismounted status, blast injuries, above-knee amputations, massive blood transfusion, and use of broad-spectrum antibiotics have all been identified as possible risk factors for the development of mould infections in military personnel [4, 9, 24, 25].

With regard to predisposing environmental conditions, people affected by natural disasters are at increased risk of both injuries and wound contamination [26, 27]. After the eruption of the Armero volcano in Colombia in 1985, mucormycosis was diagnosed in $21 \%$ of patients with necrotizing lesions (8/38) [28]. Thirteen cases of necrotizing cutaneous mucormycosis were also reported after the Joplin tornado in Missouri (USA) in 2011 [9], and several other cases of post-traumatic mould infections following natural disasters have been described [29-33]. Of note, local health structures unable to guarantee sterile irrigation of wounds and rapid care for patients with injuries may be another predisposing factor to post-traumatic mould infections during natural disasters [26, 27]. Finally, patients with burn injuries are also at increased risk of developing post-traumatic mould infections $[6,34,35]$. Overall, the general picture stemming from these epidemiological data is that wound mould infections can be observed in previously healthy people who are affected by severe trauma $[12,33,36]$. Therefore, this possibility should be considered, especially in those patients not responding to antibacterial therapy.

The second general epidemiological feature regards the aetiology of post-traumatic mould infections. Among US soldiers in Afghanistan, the most frequent moulds isolated from posttraumatic infections were Mucorales, followed by Aspergillus spp. and Fusarium spp. $[4,20,24,33]$. Reports of post-traumatic mould infections due to Mucorales are also predominant after burn-related trauma and natural disasters, although infections due to other moulds (e.g., Aspergillus spp., Scedosporium spp.) have also been reported [26, 31, 32, 37]. Of note, contaminated bandages have been identified as the possible source for an outbreak of Absidia 
corymbifera wound infections in burn patients [38].

Following natural disasters and flooding, near-drowning-related respiratory mould infections may also be observed, which represent a particular type of post-traumatic mould infection not addressed in this review [26].

\section{Pathogenesis}

Although still to be fully elucidated, the pathogenesis of mould infections following trauma injuries presents unique features compared with classical mould infections occurring in immunocompromised or diabetic patients, because a large fraction of post-traumatic mould infections is observed in previously healthy individuals [33]. In this regard, it has been observed that trauma injuries can affect the immune system, impairing both innate and adaptive immune responses $[39,40]$. In addition, severe trauma may impair phagocyte function through rhabdomyolysis-induced acidosis, which also causes a release of free iron (potentially favouring Mucorales infection) [41].

A prerequisite for post-traumatic mould infection is wound colonization by moulds [29]. After colonization exploiting the breakdown in the integrity of the cutaneous barrier, spores are able to germinate and then, in the presence of impaired phagocytosis and oxidative killing, hyphal elements can proliferate [42]. Broadspectrum antibiotics may also create favourable conditions for the development of fungal infection [42, 43]. In addition, patients suffering from blast trauma can experience stress-induced hyperglycaemia and glycosuria, which may increase the risk for developing post-traumatic mucormycosis [42, 44-46].

The growth of moulds in the wound is able to elicit an acute inflammatory response with possible abscess formation, tissue swelling, and ultimately necrosis that often progress to form black eschars $[42,47]$. If the necrotic tissue falls off, it produces large ulcers. Local invasion with cutaneous, subcutaneous tissue, adipose tissue, and muscular involvement can be observed $[42,47]$. Necrotizing fasciitis may be secondary to cutaneous or subcutaneous mould infection $[29,48,49]$. Through the bloodstream, dissemination to non-contiguous sites may occur.

\section{Diagnosis}

The clinical presentation of post-traumatic mould infections represents a challenge for physicians, ranging from minimal oedema associated with erythematous skin to necrotizing lesions with concomitant septic shock $[4,6,8]$. Absence of response to antibacterial therapy (or partial response in view of the nonnegligible prevalence of mixed bacterial-fungal infections) may help recognizing the possibility of mould infection, although, at least in at-risk categories of patients with severe traumatic injuries (e.g., soldiers, natural disasters), mould infections should already be suspected before waiting for response to antibacterials, owing to the possible rapid progression to necrosis and septic shock $[8,50,51]$.

The classical laboratory diagnostic approach to post-traumatic mould infections consists of microscopy, culture, and histopathology of infected tissues. Presumptive identification and differentiation of Mucorales from other moulds can be obtained through microscopy of wound specimens with fluorescent brighteners, although with possible suboptimal sensitivity (for both identification and differentiation) and with no identification at the genus and species level, which is achievable with culture $[18,52,53]$. Nonetheless, also cultures may be hampered by suboptimal/variable sensitivity $[4,53]$. On specimens obtained from post-traumatic wounds, cultures showed variable sensitivity in different studies, with false-negative results being observed in $17-56 \%$ of cases with positive histopathology $[13,36,54,55]$. On the other hand, up to $11 \%$ of histopathology specimens from wounds with positive cultures may not show evidence of mould infection $[13,36,54,55]$. The characteristics of classical laboratory techniques for the diagnosis of posttraumatic mould infections are summarized in Fig. 1.

The use of conventional methods (which remain mandatory) may be coupled with the 


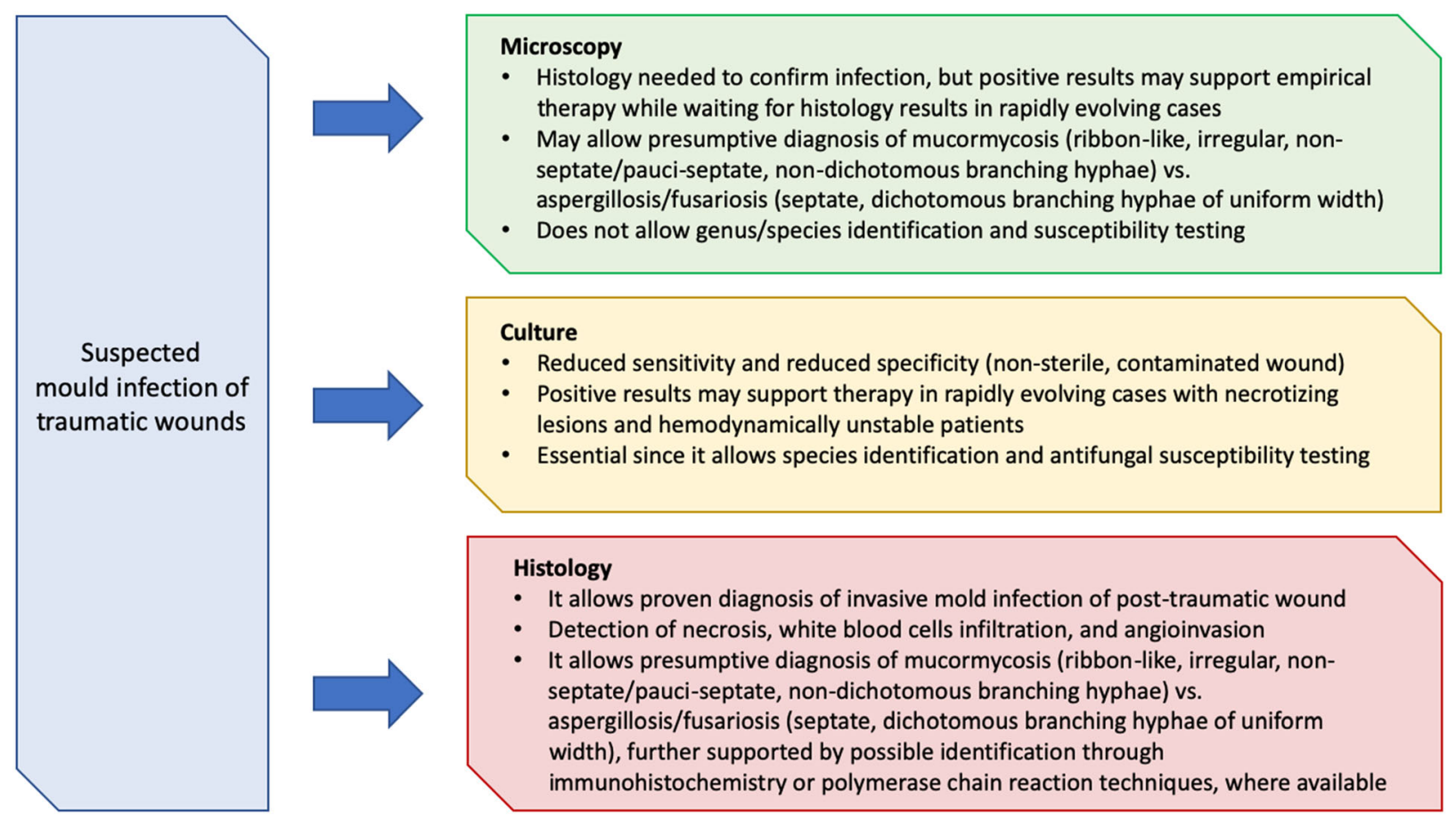

Fig. 1 Classical laboratory techniques for the diagnosis of post-traumatic mould infections. Diagnostic criteria for invasive fungal diseases in war wounds are: (1) traumatic wound; (2) recurrent necrosis after at least two consecutive

use of rapid assays for the detection of fungal antigen detection in serum and with that of polymerase chain reaction (PCR)-based tests. In the former case, negativity of both serum galactomannan and (1,3)-beta-D-glucan, especially in patients with systemic dissemination, may support the diagnosis of mucormycosis, while their positivity may conversely support the involvement of other moulds (e.g., Aspergillus spp., Fusarium spp.) [56]. PCR-based tests also represent a very useful complementary test, since they may allow earlier identification (e.g., up to 9-11 days before conventional diagnostics for mucormycosis) $[57,58]$. Nonetheless, as anticipated above, they still cannot be employed as a standalone test in view of heterogeneous performances and possible suboptimal sensitivity according to some series $[57,59]$.

Of note, some other laboratory techniques have been proposed but their discussion is beyond the scope of the present article. For interested readers, a comprehensive review of debridements; (3) positive laboratory results (i.e., positivity of mould culture and/or histological evidence of tissue invasion) $[21,64]$

novel techniques for the diagnosis of mould infections has been recently published [60].

\section{Treatment}

Most data regarding the treatment of posttraumatic mould infections come from experiences in wounded soldiers, in whom timely and aggressive surgical debridement is coupled with early and effective antifungal therapy $[4,21]$. A key challenge is the need for repeated debridement of necrotic material [25]. In a military series of post-traumatic mould infections, a median of 17 debridements was required to achieve cure [25]. In addition, amputations were necessary in 19\% of patients following scarce control with debridement and antifungal treatment [25].

Regarding antifungal therapy, although not sufficient alone due to the limited tissue penetration in the presence of vessel thrombosis and/or tissue necrosis, it remains an essential 
Table 1 Characteristics of antifungal agents for the treatment of wound mould infections following traumatic injuries

\begin{tabular}{ll}
\hline $\begin{array}{l}\text { Antifungal } \\
\text { agent }\end{array}$ & Dosage \\
\hline $\begin{array}{l}\text { Liposomal } \\
\text { amphotericin }\end{array}$ & $5-10 \mathrm{mg} / \mathrm{kg} / \mathrm{die}$ \\
$\mathrm{B}$ &
\end{tabular}

Voriconazole

Posaconazole

\footnotetext{
Intravenous

$300 \mathrm{mg} 2$ times daily on day 1 , then $300 \mathrm{mg} /$ die

Oral

$200 \mathrm{mg} 4$ times daily (oral suspension formulation); $300 \mathrm{mg} 2$ times daily on day 1 , then $300 \mathrm{mg} / \mathrm{die}$

(delayed release tablets)
}

\section{Comments}

Used as first-line therapy in most reported cases of posttraumatic mould infection of war wounds, alone or in combination with an azole agent $[10,64]$

Active against Mucorales, most Aspergillus spp., and Fusarium spp.

Inactive against Scedosporium apiospermum, Lomentospora prolificans, and Aspergillus terreus

Possible infusion-related and renal toxicity

In soldiers with mould infection of war wounds it has been used in combination with liposomal amphotericin $\mathrm{B}$ as empiric regimen until aetiological diagnosis $[10,64]$

Active against Aspergillus spp. (including Aspergillus terreus), Fusarium spp., and Scedosporium apiospermum

Inactive against Mucorales

High minimum inhibitory concentrations against Lomentospora prolificans have been reported

In soldiers with mould infection of war wounds it has been used in combination with liposomal amphotericin $\mathrm{B}$ as empiric regimen until aetiological diagnosis $[10,64]$

Active against Mucorales, Aspergillus spp. (including Aspergillus terreus), Fusarium spp., and Scedosporium apiospermum

High minimum inhibitory concentrations against Lomentospora prolificans have been reported

In the recently released global guidelines for the treatment of mucormycosis, recommended as possible salvage therapy (intravenous or delayed release tablets) after progression of disease or toxicity following initial polyene treatment, or as possible first-line therapy (intravenous) in patients with pre-existing renal failure, in setting where all classical antifungal classes are available [18] 
Table 1 continued

\begin{tabular}{|c|c|c|}
\hline $\begin{array}{l}\text { Antifungal } \\
\text { agent }\end{array}$ & Dosage & Comments \\
\hline Isavuconazole & $\begin{array}{l}\text { Intravenous } \\
200 \mathrm{mg} 3 \text { times daily on days } 1 \text { and } 2 \text {, then } \\
200 \mathrm{mg} / \text { die (from } 12-24 \mathrm{~h} \text { after the last } \\
\text { loading dose) } \\
\text { Oral } \\
200 \mathrm{mg} 3 \text { times daily on days } 1 \text { and 2, then } \\
200 \mathrm{mg} / \text { die (from } 12-24 \mathrm{~h} \text { after the last } \\
\text { loading dose) }\end{array}$ & $\begin{array}{l}\text { Limited experience in the treatment of post-traumatic } \\
\text { mould infections } \\
\text { Active against Mucorales, Aspergillus spp. (including } \\
\text { Aspergillus terreus), Fusarium spp., and Scedosporium } \\
\text { apiospermum } \\
\text { High minimum inhibitory concentrations against } \\
\text { Lomentospora prolificans have been reported } \\
\text { In the recently released global guidelines for the } \\
\text { treatment of mucormycosis, recommended as possible } \\
\text { salvage therapy (intravenous) after progression of } \\
\text { disease or toxicity following initial polyene treatment, } \\
\text { or as possible first-line therapy (intravenous) in } \\
\text { patients with pre-existing renal failure, in setting } \\
\text { where all classical antifungal classes are available [18] }\end{array}$ \\
\hline
\end{tabular}

component of the therapeutic approach to posttraumatic mould infections. The usual drug of choice for empirical antifungal treatment, for its broad-spectrum of activity against moulds, its efficacy against Mucorales, most Aspergillus spp., and Fusarium spp, and its bactericidal activity, is liposomal amphotericin B (L-AmB) [12]. A combination of L-AmB with voriconazole (which is inactive against Mucorales but retain activity against Aspergillus terreus and Scedosporium apiospermum, which are resistant to L-AmB) was the most frequent empirical regimen employed $(71 \%, 55 / 77)$ in a series of soldiers with post-traumatic mould infections and recurrent necrosis, followed by a maintenance regimen with liposomal amphotericin $\mathrm{B}$ after proven diagnosis of mucormycosis [20]. The possible role of isavuconazole in the setting of post-traumatic mucormycosis still needs to be fully elucidated.

Owing to the above-mentioned concern about poor tissue penetration of antifungal treatment in the presence of angio-necrosis and tissue necrosis, local therapies may be considered [25]. Sodium hypochlorite (Dakin's solution at $0.025 \%)$, combined with the use of vacuum-assisted closure (VAC) therapy, surgical debridement, and systemic antifungal therapy, is used for the local treatment of mould infections following war wounds [61]. Topical L-AmB and nystatin have also been used in some settings, although no randomized controlled trials have been conducted $[25,62]$.

Of note, the treatment of post-traumatic mould infections is further complicated by the fact that many wounds may grow different moulds [63]. For example, combinations of Mucorales, Aspergillus spp., and Fusarium spp. have been found in an observational cohort study of infectious complications among military personnel injured during war in Iraq and Afghanistan [64]. Furthermore, post-traumatic wounds can also be infected with bacteria; thus, an antibiotic treatment should also be promptly started empirically and revaluated according to the course of the disease and laboratory results [25].

Finally, the necessary length of antifungal treatment is still not completely clear and frequently individualized [33]. In general, continuation of treatment at least until full surgical repair of the wound is warranted. On the other hand, empiric antifungal therapy should be 
Table 2 Isolated moulds, surgical treatment, and outcome of mould wound infections in case series and case reports published in the last decade

\begin{tabular}{|c|c|c|c|c|}
\hline $\begin{array}{l}\text { Author (year) } \\
\text { [ref] }\end{array}$ & $\begin{array}{l}\text { Type of trauma (isolated } \\
\text { mould/s) }\end{array}$ & $\begin{array}{l}\text { No. of } \\
\text { patients }\end{array}$ & $\begin{array}{l}\text { Reported surgical debridement and/ } \\
\text { or amputation in addition to } \\
\text { antifungal therapy } \\
\text { No. of patients (\%) }\end{array}$ & $\begin{array}{l}\text { Mortality } \\
\text { No. (\%) }\end{array}$ \\
\hline $\begin{array}{l}\text { Wilson et al. } \\
\text { (2019) [65] }\end{array}$ & Traffic accident (Rhizopus spp.) & 1 & $\begin{array}{l}\text { Multiple surgical debridements } \\
1 / 1(100)\end{array}$ & $0 / 1(0)$ \\
\hline $\begin{array}{l}\text { Lelievre et al. } \\
\text { (2014) [12] }\end{array}$ & $\begin{array}{l}\text { Traffic accidents, farm working } \\
\text { accidents, blast injuries * (Rhizopus } \\
\text { spp., Lichtheimia spp., Mucor spp., } \\
\text { Saksenaea spp., Apophysomyces spp.) }\end{array}$ & 16 & $\begin{array}{l}\text { Multiple surgical debridements } \\
6 / 16(37.5) \\
\text { Amputation } \\
2 / 16(12.5)\end{array}$ & $2 / 16(12.5)$ \\
\hline $\begin{array}{l}\text { Rodriguez et al. } \\
\qquad(2014)[20]^{* *}\end{array}$ & $\begin{array}{l}\text { Combat-related injuries (Mucorales, } \\
\text { Aspergillus spp., other moulds) }\end{array}$ & 96 & $\begin{array}{l}\text { Multiple surgical debridements } \\
96 / 96 \text { (100) } \\
\text { High-level amputations (total hip } \\
\text { disarticulation or hemipelvectomy) } \\
\text { 16/96 (16.7) }\end{array}$ & $6 / 96(6.3)$ \\
\hline $\begin{array}{l}\text { Neblett Fanfair } \\
\text { et al. (2012) } \\
\text { [9] }\end{array}$ & $\begin{array}{l}\text { Tornado-related trauma } \\
\text { (Apophysomyces spp., Aspergillus } \\
\text { spp., Mucor spp., Fusarium spp.) }\end{array}$ & 13 & $\begin{array}{l}\text { Surgical debridement } \\
13 / 13(100)\end{array}$ & $5 / 13(38.5)$ \\
\hline $\begin{array}{l}\text { Vitrat-Hincky } \\
\text { et al. (2009) } \\
{[13]}\end{array}$ & $\begin{array}{l}\text { Traffic accidents, farm working } \\
\text { accidents (Mucorales, Aspergillus } \\
\text { spp., Fusarium spp.) }\end{array}$ & 6 & $\begin{array}{l}\text { Amputation } \\
5 / 6(83.3) \\
\text { Large musculocutaneous excision } \\
1 / 6(16.7)\end{array}$ & $0 / 6(0)$ \\
\hline $\begin{array}{l}\text { Tully et al. } \\
\text { (2009) [7] }\end{array}$ & $\begin{array}{l}\text { Combat-related injuries } \\
\text { (Actinomucor spp.) }\end{array}$ & 1 & $\begin{array}{l}\text { Surgical debridement } \\
1 / 1(100)\end{array}$ & $1 / 1(100)$ \\
\hline $\begin{array}{l}\text { Arnaiz-Garcia } \\
\text { et al. (2009) } \\
{[55]}\end{array}$ & $\begin{array}{l}\text { Various (Mucor spp, } \\
\text { Rhizomucor spp., Lichtheimia spp.) }\end{array}$ & 5 & $\begin{array}{l}\text { Surgical debridement } \\
3 / 5(60) \\
\text { Amputation } \\
2 / 5(40)\end{array}$ & $0 / 5(0)$ \\
\hline $\begin{array}{l}\text { Corti et al. } \\
\text { (2009) [66] }\end{array}$ & $\begin{array}{l}\text { Traffic accident (Lichtheimia } \\
\text { spp.) }\end{array}$ & 1 & $\begin{array}{l}\text { Surgical debridement } \\
1 / 1(100) \\
\text { Amputation } \\
1 / 1(100)\end{array}$ & $0 / 1(0)$ \\
\hline $\begin{array}{l}\text { Volkmer et al. } \\
\text { (2009) [67] }\end{array}$ & $\begin{array}{l}\text { Traffic accident (Mucor spp., } \\
\text { Aspergillus spp., Fusarium spp.) }\end{array}$ & 1 & $\begin{array}{l}\text { Surgical debridement } \\
1 / 1(100)\end{array}$ & $0 / 1(0)$ \\
\hline
\end{tabular}


Table 2 continued

\begin{tabular}{|c|c|c|c|c|}
\hline $\begin{array}{l}\text { Author (year) } \\
\text { [ref] }\end{array}$ & $\begin{array}{l}\text { Type of trauma (isolated } \\
\text { mould/s) }\end{array}$ & $\begin{array}{l}\text { No. of } \\
\text { patients }\end{array}$ & $\begin{array}{l}\text { Reported surgical debridement and/ } \\
\text { or amputation in addition to } \\
\text { antifungal therapy } \\
\text { No. of patients }(\%)\end{array}$ & $\begin{array}{l}\text { Mortality } \\
\text { No. (\%) }\end{array}$ \\
\hline $\begin{array}{l}\text { Stasiak et al. } \\
\text { (2009) [68] }\end{array}$ & Traffic accident (Mucor spp.) & 1 & $\begin{array}{l}\text { Surgical debridement } \\
1 / 1(100) \\
\text { Amputation } \\
1 / 1(100)\end{array}$ & $1 / 1(100)$ \\
\hline $\begin{array}{l}\text { Ozer et al. } \\
\text { (2009) [69] }\end{array}$ & Farm accident (Aspergillus spp.) & 1 & $\begin{array}{l}\text { Surgical debridement } \\
1 / 1(100)\end{array}$ & $0 / 1(0)$ \\
\hline $\begin{array}{l}\text { Stewardson et al. } \\
\text { (2009) [70] }\end{array}$ & Swimming accident (Saksenaea spp.) & 1 & $\begin{array}{l}\text { Surgical debridement } \\
1 / 1(100)\end{array}$ & $0 / 1(0)$ \\
\hline $\begin{array}{l}\text { Blazquez et al. } \\
(2010)[71]\end{array}$ & Traffic accident (Lichtheimia spp.) & 1 & $\begin{array}{l}\text { Surgical debridement } \\
1 / 1(100)\end{array}$ & $0 / 1(0)$ \\
\hline $\begin{array}{l}\text { Van Sickels et al. } \\
\text { (2011) [72] }\end{array}$ & Gun shots wounds (Rhizopus spp.) & 1 & $\begin{array}{l}\text { Surgical debridement } \\
1 / 1(100)\end{array}$ & $0 / 1(0)$ \\
\hline $\begin{array}{l}\text { Hospenthal et al. } \\
\text { (2011) [73] }\end{array}$ & $\begin{array}{l}\text { Combat-related injuries (Saksenaea } \\
\text { spp.) }\end{array}$ & 1 & $\begin{array}{l}\text { Multiple surgical debridements } \\
1 / 1(100)\end{array}$ & $1 / 1(100)$ \\
\hline $\begin{array}{l}\text { Rabie et al. } \\
\qquad(2012)[74]\end{array}$ & Traffic accident (Rhizopus spp.) & 1 & Not described & NA \\
\hline $\begin{array}{l}\text { Paolino et al. } \\
\text { (2012) [75] }\end{array}$ & $\begin{array}{l}\text { Combat-related injuries (Aspergillus } \\
\text { spp., Fusarium spp., Mucorales, } \\
\text { others) }\end{array}$ & 6 & $\begin{array}{l}\text { Multiple debridements } \\
6 / 6(100) \\
\text { Amputation } \\
3 / 6(50)\end{array}$ & $0 / 6(0)$ \\
\hline $\begin{array}{l}\text { Mayayo et al. } \\
(2013 \text { [76] }\end{array}$ & Traffic accident (Saksenaea spp.) & 1 & $\begin{array}{l}\text { Surgical debridement } \\
1 / 1(100)\end{array}$ & $1 / 1(100)$ \\
\hline $\begin{array}{l}\text { Pozo-Laderas } \\
\text { et al. (2015) } \\
\text { [77] }\end{array}$ & Traffic accident (Rhizomucor spp.) & 1 & $\begin{array}{l}\text { Multiple surgical interventions } \\
\text { (disseminated infection) } \\
1 / 1 \text { (100) }\end{array}$ & $0 / 1(0)$ \\
\hline $\begin{array}{l}\text { Tak et al. } \\
\text { (2013) [78] }\end{array}$ & Traffic accident (Aspergillus spp.) & 1 & $\begin{array}{l}\text { Surgical debridement } \\
1 / 1(100)\end{array}$ & $0 / 1(0)$ \\
\hline $\begin{array}{l}\text { Poirier et al. (2013) } \\
\text { [79] }\end{array}$ & Various (Lichtheimia spp. ${ }^{* * *}$ ) & 3 & $\begin{array}{l}\text { Surgical debridement } \\
1 / 3(33.3) \\
\text { Amputation } \\
1 / 3(33.3)\end{array}$ & $1 / 3(33.3)$ \\
\hline
\end{tabular}


Table 2 continued

\begin{tabular}{|c|c|c|c|c|}
\hline $\begin{array}{l}\text { Author (year) } \\
\text { [ref] }\end{array}$ & $\begin{array}{l}\text { Type of trauma (isolated } \\
\text { mould } / \mathrm{s} \text { ) }\end{array}$ & $\begin{array}{l}\text { No. of } \\
\text { patients }\end{array}$ & $\begin{array}{l}\text { Reported surgical debridement and/ } \\
\text { or amputation in addition to } \\
\text { antifungal therapy } \\
\text { No. of patients }(\%)\end{array}$ & $\begin{array}{l}\text { Mortality } \\
\text { No. (\%) }\end{array}$ \\
\hline $\begin{array}{l}\text { Gómez- } \\
\text { Camarasa } \\
\text { et al. (2014) } \\
\text { [80] }\end{array}$ & Farm accident (Saksenaea spp.) & 1 & $\begin{array}{l}\text { Multiple debridements } \\
1 / 1(100)\end{array}$ & $1 / 1(100)$ \\
\hline $\begin{array}{l}\text { Lundy et al. } \\
\qquad(2014)[81]\end{array}$ & Combat-related injuries (Mucorales) & 2 & $\begin{array}{l}\text { Surgical debridement and proctectomy } \\
2 / 2(100)\end{array}$ & $0 / 2(0)$ \\
\hline $\begin{array}{l}\text { Tyll et al. (2016) } \\
\text { [82] }\end{array}$ & Traffic accident (Lichtheimia spp.) & 1 & $\begin{array}{l}\text { Amputation } \\
1 / 1(100)\end{array}$ & $0 / 1(0)$ \\
\hline $\begin{array}{l}\text { Obradović- } \\
\text { Tomasev et al. } \\
\text { (2016) [19] }\end{array}$ & $\begin{array}{l}\text { Corn-picker hand injuries (Aspergillus } \\
\text { spp., Mucor spp.) }\end{array}$ & 8 & $\begin{array}{l}\text { Multiple surgical debridements } \\
8 / 8(100)\end{array}$ & $0 / 8(0)$ \\
\hline $\begin{array}{l}\text { Kyriopoulos } \\
\text { et al. (2015) } \\
\text { [83] }\end{array}$ & $\begin{array}{l}\text { Traffic accident (Rhizomucor spp., } \\
\text { Rhizopus spp.) }\end{array}$ & 2 & $\begin{array}{l}\text { Surgical debridement } \\
2 / 2(100)\end{array}$ & $0 / 2(0)$ \\
\hline $\begin{array}{l}\text { Kite et al. } \\
\qquad(2016)[84]\end{array}$ & $\begin{array}{l}\text { Garden rake injury (Scedosporium } \\
\text { spp.) }\end{array}$ & 1 & $\begin{array}{l}\text { Surgical debridement } \\
1 / 1(100)\end{array}$ & $0 / 1(0)$ \\
\hline $\begin{array}{l}\text { Liu et al. } \\
\qquad(2017)[85]\end{array}$ & Branch scratch (Aspergillus spp.) & 1 & None & $0 / 1(0)$ \\
\hline $\begin{array}{l}\text { Egge et al. } \\
\qquad(2018)[86]\end{array}$ & Traffic accident (Apophysomyces spp.) & 1 & $\begin{array}{l}\text { Multiple debridements } \\
1 / 1(100)\end{array}$ & $1 / 1(100)$ \\
\hline $\begin{array}{l}\text { Sękowska et al. } \\
\text { (2019) [87] }\end{array}$ & Traffic accident (Mucor spp.) & 1 & $\begin{array}{l}\text { Amputation } \\
1 / 1(100)\end{array}$ & $0 / 1(100)$ \\
\hline
\end{tabular}

NA, not available. Comprehensive summaries of management of post-traumatic mould wound injuries in previous decades and in burn patients are available elsewhere $[13,34]$

* Some cases of burn or postoperative mould wound infections were also included $(4 / 16)$

${ }^{* *}$ Cohort overlapping with that of other studies investigating different aspects of combat-related injuries [10, 21, 24, 50, 63]

${ }^{* * *}$ Possible cross-transmission

stopped as soon as mould infection is no longer suspected [25].

The characteristics of systemic antifungal agents for the treatment of mould wound infections after traumatic injuries are summarized in Table 1, whereas additional information on isolated moulds, surgical treatment and outcome of mould wound infections in some series published in the last decade is presented in Table 2. 


\section{CONCLUSIONS}

Most of the published clinical experience and research regarding wound mould infections following traumatic injuries regards soldiers and natural disasters. However, these infections may also be observed in other immunocompetent individuals with trauma and soil contamination (e.g., agricultural or automotive injuries). In such cases, diagnosis and treatment could be delayed due to lack of awareness of mould infections during routine care. Clinical signs such as necrosis and reduced response to antibacterial therapy should be promptly identified to rapidly start an adequate laboratory workflow and empirical antifungal therapy in rapidly evolving cases.

\section{ACKNOWLEDGEMENTS}

Funding. No funding or sponsorship was received for this study or publication of this article.

Authorship. All named authors meet the International Committee of Medical Journal Editors (ICMJE) criteria for authorship for this article, take responsibility for the integrity of the work as a whole, and have given their approval for this version to be published.

Disclosures. Outside the submitted work, Matteo Bassetti has participated in advisory boards and/or received speaker honoraria from Achaogen, Angelini, Astellas, Bayer, Basilea, BioMérieux, Cidara, Gilead, Menarini, MSD, Nabriva, Paratek, Pfizer, Roche, Melinta, Shionogi, Tetraphase, VenatoRx and Vifor and has received study grants from Angelini, Basilea, Astellas, Shionogi, Cidara, Melinta, Gilead, Pfizer and MSD. Matteo Bassetti is a member of the journal's Editorial Board. Outside the submitted work, Daniele Roberto Giacobbe reports honoraria from Stepstone Pharma $\mathrm{GmbH}$ and an unconditional grant from MSD Italia. Niccolò Riccardi and Antonio Vena have no conflicts of interest to disclose.
Compliance with Ethics Guidelines. This article is based on previously conducted studies and does not contain any studies with human or animal subjects performed by either of the authors.

Data Availability. Data sharing is not applicable to this article as no datasets were generated or analysed in the current study.

Open Access. This article is distributed under the terms of the Creative Commons Attribution-NonCommercial 4.0 International License (http://creativecommons.org/licenses/ by-nc/4.0/), which permits any noncommercial use, distribution, and reproduction in any medium, provided you give appropriate credit to the original author(s) and the source, provide a link to the Creative Commons license, and indicate if changes were made.

Open Access. This article is distributed under the terms of the Creative Commons Attribution-NonCommercial 4.0 International License (http://creativecommons.org/licenses/ by-nc/4.0/), which permits any noncommercial use, distribution, and reproduction in any medium, provided you give appropriate credit to the original author(s) and the source, provide a link to the Creative Commons license, and indicate if changes were made.

\section{REFERENCES}

1. Sanguinetti M, Posteraro B, Beigelman-Aubry C, et al. Diagnosis and treatment of invasive fungal infections: looking ahead. J Antimicrob Chemother. 2019;74(Supplement_2):ii27-37.

2. Jose P, Alvarez-Lerma F, Maseda E, et al. Invasive fungal infection in crtically ill patients: hurdles and next challenges. J Chemother. 2019;31(2):64-73.

3. Riccardi N, Rotulo GA, Castagnola E. Definition of opportunistic infections in immunocompromised children on the base of etiologies and clinical features: a summary for practical purposes. Curr Pediatr Rev. 2019. 
4. Kronen R, Liang SY, Bochicchio G, et al. Invasive fungal infections secondary to traumatic injury. Int J Infect Dis. 2017;62:102-11.

5. Sanz Alonso MA, Jarque Ramos I, Salavert M, et al. Epidemiology of invasive fungal infections due to Aspergillus spp. and Zygomycetes. Clin Microbiol Infection. 2006;12:2-6.

6. Skiada A, Rigopoulos D, Larios G, et al. Global epidemiology of cutaneous zygomycosis. Clin Dermatol. 2012;30(6):628-32.

7. Tully CC, Romanelli AM, Sutton DA, et al. Fatal Actinomucor elegans var. kuwaitiensis infection following combat trauma. J Clin Microbiol. 2009;47(10):3394-9.

8. Zahoor B, Kent S, Wall D. Cutaneous mucormycosis secondary to penetrative trauma. Injury. 2016;47(7):1383-7.

9. Neblett Fanfair R, Benedict K, Bos J, et al. Necrotizing cutaneous mucormycosis after a tornado in Joplin, Missouri, in 2011. N Engl J Med. 2012;367(23):2214-25.

10. Warkentien T, Rodriguez C, Lloyd B, et al. Invasive mold infections following combat-related injuries. Clin Infect Dis. 2012;55(11):1441-9.

11. Hajdu S, Obradovic A, Presterl E, et al. Invasive mycoses following trauma. Injury. 2009;40(5): 548-54.

12. Lelievre L, Garcia-Hermoso D, Abdoul H, et al. Posttraumatic mucormycosis: a nationwide study in France and review of the literature. Medicine (Baltimore). 2014;93(24):395-404.

13. Vitrat-Hincky V, Lebeau B, Bozonnet E, et al. Severe filamentous fungal infections after widespread tissue damage due to traumatic injury: six cases and review of the literature. Scand $J$ Infect Dis. 2009;41(6-7):491-500.

14. Dave TV, Dave VP, Sharma S, et al. Infectious endophthalmitis leading to evisceration: spectrum of bacterial and fungal pathogens and antibacterial susceptibility profile. J Ophthalmic Inflamm Infect. 2019;9(1):9.

15. Bitar D, Van Cauteren D, Lanternier F, et al. Increasing incidence of zygomycosis (mucormycosis), France, 1997-2006. Emerg Infect Dis. 2009;15(9):1395-401.

16. Bouza E, Muñoz P, Guinea J. Mucormycosis: an emerging disease? Clin Microbiol Infect. 2006;12: $7-23$.
17. Torres-Narbona M, Guinea J, Martinez-Alarcon J, et al. Impact of zygomycosis on microbiology workload: a survey study in Spain. J Clin Microbiol. 2007;45(6):2051-3.

18. Cornely OA, Alastruey-Izquierdo A, Arenz D, et al. Global guideline for the diagnosis and management of mucormycosis: an initiative of the European Confederation of Medical Mycology in cooperation with the Mycoses Study Group Education and Research Consortium. Lancet Infect Dis. 2019.

19. Obradovic-Tomasev M, Jovanovic M, Vuckovic N, et al. Fungal infections in corn picker hand injury. Srp Arh Celok Lek. 2016;144(1-2):52-5.

20. Rodriguez C, Weintrob AC, Dunne JR, et al. Clinical relevance of mold culture positivity with and without recurrent wound necrosis following combat-related injuries. J Trauma Acute Care Surg. 2014;77(5):769-73.

21. Weintrob AC, Weisbrod AB, Dunne JR, et al. Combat trauma-associated invasive fungal wound infections: epidemiology and clinical classification. Epidemiol Infect. 2015;143(1):214-24.

22. Radowsky JS, Brown TS, Lisboa FA, et al. Serum inflammatory cytokine markers of invasive fungal infection in previously immunocompetent battle casualties. Surg Infect (Larchmt). 2015;16(5): 526-32.

23. Kimura F, Shimizu $H$, Yoshidome $H$, et al. Immunosuppression following surgical and traumatic injury. Surg Today. 2010;40(9):793-808.

24. Lewandowski LR, Weintrob AC, Tribble DR, et al. Early complications and outcomes in combat injury-related invasive fungal wound infections: a case-control analysis. J Orthop Trauma. 2016;30(3): e93-9.

25. Tribble DR, Rodriguez CJ. Combat-related invasive fungal wound infections. Curr Fungal Infect Rep. 2014;8(4):277-86.

26. Benedict K, Park BJ. Invasive fungal infections after natural disasters. Emerg Infect Dis. 2014;20(3): 349-55.

27. Ivers LC, Ryan ET. Infectious diseases of severe weather-related and flood-related natural disasters. Curr Opin Infect Dis. 2006;19(5):408-14.

28. Patino JF, Castro D, Valencia A, et al. Necrotizing soft tissue lesions after a volcanic cataclysm. World J Surg. 1991;15(2):240-7.

29. Richardson M. The ecology of the Zygomycetes and its impact on environmental exposure. Clin Microbiol Infect. 2009;15(Suppl 5):2-9. 
30. Andresen D, Donaldson A, Choo L, et al. Multifocal cutaneous mucormycosis complicating polymicrobial wound infections in a tsunami survivor from Sri Lanka. Lancet. 2005;365(9462):876-8.

31. Maegele M, Gregor S, Yuecel N, et al. One year ago not business as usual: wound management, infection and psychoemotional control during tertiary medical care following the 2004 Tsunami disaster in southeast Asia. Crit Care. 2006;10(2):R50.

32. Snell BJ, Tavakoli K. Necrotizing fasciitis caused by Apophysomyces elegans complicating soft-tissue and pelvic injuries in a tsunami survivor from Thailand. Plast Reconstr Surg. 2007;119(1):448-9.

33. Walsh TJ, Hospenthal DR, Petraitis V, et al. Necrotizing mucormycosis of wounds following combat injuries, natural disasters, burns, and other trauma. Journal of fungi (Basel, Switzerland). 2019;5(3).

34. Devauchelle P, Jeanne M, Frealle E. Mucormycosis in burn patients. Journal of fungi (Basel, Switzerland). 2019;5(1).

35. Ledgard JP, van Hal S, Greenwood JE. Primary cutaneous zygomycosis in a burns patient: a review. J Burn Care Res. 2008;29(2):286-90.

36. Lanternier F, Dannaoui E, Morizot G, et al. A global analysis of mucormycosis in France: the RetroZygo Study (2005-2007). Clin Infect Dis. 2012;54(Suppl 1):S35-43.

37. Kordy FN, Al-Mohsen IZ, Hashem F, et al. Successful treatment of a child with posttraumatic necrotizing fasciitis caused by Apophysomyces elegans: case report and review of literature. Pediatr Infect Dis J. 2004;23(9):877-9.

38. Christiaens G, Hayette MP, Jacquemin D, et al. An outbreak of Absidia corymbifera infection associated with bandage contamination in a burns unit. J Hosp Infect. 2005;61(1):88.

39. Gupta DL, Bhoi S, Mohan T, et al. Coexistence of Th1/Th2 and Th17/Treg imbalances in patients with post traumatic sepsis. Cytokine. 2016;88: 214-21.

40. Leliefeld PH, Wessels CM, Leenen LP, et al. The role of neutrophils in immune dysfunction during severe inflammation. Crit Care. 2016;23(20):73.

41. Spellberg B, Edwards J Jr, Ibrahim A. Novel perspectives on mucormycosis: pathophysiology, presentation, and management. Clin Microbiol Rev. $2005 ; 18(3): 556-69$.

42. Ribes JA, Vanover-Sams CL, Baker DJ. Zygomycetes in human disease. Clin Microbiol Rev. 2000;13(2): 236-301.
43. Torack RM. Fungus infections associated with antibiotic and steroid therapy. Am J Med. 1957;22(6):872-82.

44. Arney GK, Pearson E, Sutherland AB. Burn stress pseudodiabetes. Ann Surg. 1960;152:77-90.

45. Vainrub B, Macareno A, Mandel S, et al. Wound zygomycosis (mucormycosis) in otherwise healthy adults. Am J Med. 1988;84(3 Pt 1):546-8.

46. Petrikkos G, Drogari-Apiranthitou M. Zygomycosis in immunocompromised non-haematological patients. Mediterr J Hematol Infect Dis. 2011;3(1): e2011012.

47. Nash G, Foley FD, Goodwin MN Jr, et al. Fungal burn wound infection. JAMA. 1971;215(10): 1664-6.

48. Castrejon-Perez AD, Welsh EC, Miranda I, et al. Cutaneous mucormycosis. An Bras Dermatol. 2017;92(3):304-11.

49. Moran SL, Strickland J, Shin AY. Upper-extremity mucormycosis infections in immunocompetent patients. J Hand Surg Am. 2006;31(7):1201-5.

50. Lloyd B, Weintrob AC, Rodriguez C, et al. Effect of early screening for invasive fungal infections in U.S. service members with explosive blast injuries. Surg Infect (Larchmt). 2014;15(5):619-26.

51. De Pauw B, Walsh TJ, Donnelly JP, et al. Revised definitions of invasive fungal disease from the European Organization for Research and Treatment of Cancer/Invasive Fungal Infections Cooperative Group and the National Institute of Allergy and Infectious Diseases Mycoses Study Group (EORTC/ MSG) Consensus Group. Clin Infect Dis. 2008;46(12):1813-21.

52. Monheit JE, Cowan DF, Moore DG. Rapid detection of fungi in tissues using calcofluor white and fluorescence microscopy. Arch Pathol Lab Med. 1984;108(8):616-8.

53. Lass-Florl C. Zygomycosis: conventional laboratory diagnosis. Clin Microbiol Infect. 2009;15(Suppl 5): 60-5.

54. Jain D, Kumar Y, Vasishta RK, et al. Zygomycotic necrotizing fasciitis in immunocompetent patients: a series of 18 cases. Mod Pathol. 2006;19(9):1221-6.

55. Arnaiz-Garcia ME, Alonso-Pena D, Gonzalez-Vela Mdel C, et al. Cutaneous mucormycosis: report of five cases and review of the literature. J Plast Reconstr Aesthet Surg. 2009;62(11):e434-41.

56. Giacobbe DR, Del Bono V, Viscoli C, et al. Use of 1,3 -beta-D-glucan in invasive fungal diseases in 
hematology patients. Expert Rev Anti Infect Ther. 2017;15(12):1101-12.

57. Millon L, Herbrecht R, Grenouillet F, et al. Early diagnosis and monitoring of mucormycosis by detection of circulating DNA in serum: retrospective analysis of 44 cases collected through the French Surveillance Network of Invasive Fungal Infections (RESSIF). Clin Microbiol Infect. 2016;22(9):810e1-8.

58. Legrand M, Gits-Muselli M, Boutin L, et al. Detection of circulating mucorales DNA in critically ill burn patients: preliminary report of a screening strategy for early diagnosis and treatment. Clin Infect Dis. 2016;63(10):1312-7.

59. Ruping MJ, Heinz WJ, Kindo AJ, et al. Forty-one recent cases of invasive zygomycosis from a global clinical registry. J Antimicrob Chemother. 2010;65(2):296-302.

60. Mercier T, Guldentops E, Van Daele R, et al. Diagnosing invasive mold infections: what is next. Curr Fungal Infect Rep. 2018;12(4):161-9.

61. Hirsch EF. "The Treatment of Infected Wounds," Alexis Carrel's contribution to the care of wounded soldiers during World War I. J Trauma. 2008;64(3 Suppl):S209-10.

62. Barret JP, Ramzy PI, Heggers JP, et al. Topical nystatin powder in severe burns: a new treatment for angioinvasive fungal infections refractory to other topical and systemic agents. Burns. 1999;25(6): 505-8.

63. Warkentien TE, Shaikh F, Weintrob AC, et al. Impact of mucorales and other invasive molds on clinical outcomes of polymicrobial traumatic wound infections. J Clin Microbiol. 2015;53(7): 2262-70.

64. Rodriguez CJ, Tribble DR, Malone DL, et al. Treatment of suspected invasive fungal infection in war wounds. Mil Med. 2018;183(suppl_2):142-6.

65. Wilson W, Ali-Osman F, Sucher J, et al. Invasive fungal wound infection in an otherwise healthy trauma patient (Mucor Trauma). Trauma Case Rep. 2019;20(24):100251.

66. Corti G, Mondanelli N, Losco M, et al. Post-traumatic infection of the lower limb caused by rare Enterobacteriaceae and Mucorales in a young healthy male. Int J Infect Dis. 2009;13(2):e57-60.

67. Volkmer E, Mathonia P, Hummel T, et al. Successful nystatin powder treatment of posttraumatic invasive Aspergillus fumigatus wound infection refractory to systemic antifungal therapy. J Trauma. 2009;67(6):E197-201.
68. Stasiak M, Samet A, Lasek J, et al. Mucormycosis complicating lower limb crash injury in a multiple traumatised patient: an unusual case. BMJ Case Rep. 2009;2009.

69. Ozer B, Kalaci A, Duran N, et al. Cutaneous infection caused by Aspergillus terreus. J Med Microbiol. 2009;58(Pt 7):968-70.

70. Stewardson AJ, Holmes NE, Ellis DH, et al. Cutaneous zygomycosis caused by Saksenaea vasiformis following water-related wound in a 24-year-old immunocompetent woman. Mycoses. 2009;52(6): 547-9.

71. Blazquez D, Ruiz-Contreras J, Fernández-Cooke E, et al. Lichtheimia corymbifera subcutaneous infection successfully treated with amphotericin B, early debridement, and vacuum-assisted closure. J Pediatr Surg. 2010;45(12):e13-5.

72. Van Sickels N, Hoffman J, Stuke L, et al. Survival of a patient with trauma-induced mucormycosis using an aggressive surgical and medical approach. J Trauma. 2011;70(2):507-9.

73. Hospenthal DR, Chung KK, Lairet K, et al. Saksenaea erythrospora infection following combat trauma. J Clin Microbiol. 2011;49(10):3707-9.

74. Rabie NB, Althaqafi AO. Rhizopus-associated soft tissue infection in an immunocompetent air-conditioning technician after a road traffic accident: a case report and review of the literature. J Infect Public Health. 2012;5(1):109-11.

75. Paolino KM, Henry JA, Hospenthal DR, et al. Invasive fungal infections following combat-related injury. Mil Med. 2012;177(6):681-5.

76. Mayayo E, Stchigel AM, Cano JF, et al. Necrotising fasciitis caused by Saksenaea vasiformis in an immunocompetent patient after a car accident. Rev Iberoam Micol. 2013;30(1):57-60.

77. Pozo-Laderas JC, Pontes-Moreno A, Robles-Arista JC, et al. Mixed invasive fungal infection due to Rhizomucor pusillus and Aspergillus niger in an immunocompetent patient. Rev Iberoam Micol. 2015;32(1):46-50.

78. Tak V, Mathur P, Xess I, et al. A case of dual infection in a paediatric trauma victim of primary cutaneous aspergillosis caused by Aspergillus flavus and Aspergillus terreus. Indian J Med Microbiol. 2013;31(2):193-6.

79. Poirier P, Nourrisson C, Gibold L, et al. Three cases of cutaneous mucormycosis with Lichtheimia spp. (ex Absidia/Mycocladus) in ICU. Possible crosstransmission in an intensive care unit between 2 cases. J Mycol Med. 2013;23(4):265-9. 
80. Gómez-Camarasa C, Rojo-Martín MD, MirandaCasas C, et al. Disseminated infection due to Saksenaea vasiformis secondary to cutaneous mucormycosis. Mycopathologia. 2014;177(1-2): 97-101.

81. Lundy JB, Driscoll IR. Experience with proctectomy to manage combat casualties sustaining catastrophic perineal blast injury complicated by invasive mucor soft-tissue infections. Mil Med. 2014;179(3):e347-50.

82. Tyll T, Lyskova P, Hubka V, et al. Early diagnosis of cutaneous mucormycosis due to Lichtheimia corymbifera after a traffic accident. Mycopathologia. 2016;181(1-2):119-24.

83. Kyriopoulos EJ, Kyriakopoulos A, Karonidis A, et al. Burn injuries and soft tissue traumas complicated by mucormycosis infection: a report of six cases and review of the literature. Ann Burns Fire Disasters. 2015;28(4):280-7.

84. Kite BW, Heng T. An atypical foot infection. Aust Fam Physician. 2016;45(11):819-20.

85. Liu X, Yang J, Ma W. Primary cutaneous aspergillosis caused by Aspergillus fumigatus in an immunocompetent patient: a case report. Medicine (Baltimore). 2017;96(48):e8916.

86. Egge S, Wei E, Clements E, et al. Post-traumatic fatal disseminated Apophysomyces elegans infection. Med Mycol Case Rep. 2018;6(22):45-7.

87. Sękowska A, Prażyńska M, Twarużek M, et al. Fulminant mucormycosis after a traffic accident: a case report. Folia Microbiol (Praha). 2019;64(3):429-33. 